\title{
OF THE EARLY COMPLEX OF KOSHKINSKAY SITE ON VYATKA RIVER RIGHT BANK
}

(C)2014

T.M.Gusentzova, research associate

Autonomous Non-commercial Organization «Scientific and Research Institute for Cultural and Natural Heritage», S-Peterburg (Russia)

Annotation: On Koshkinskay site it is found 9 constructions, more than 30 holes in which the stone stock and pottery is concentrated are found. The site repeatedly became populated by the ancient population in 6 millennium BC. The part of ware can be carried to a late stage elshansky, another to srednevolzhsky to cultures of an early Neolithic.

Keywords: early Neolithic; constructions; ceramics; stone stock; elashansky and srednevolzhsky cultures.

УДК902

(C) 2014

\section{NEOLITHIC FLINT ASSEMBLAGES FROM BULGARIA: AN OVERVIEW}

\author{
National Institute of Archaeology and Museum Bulgarian Academy of Sciences, Sofia (Bulgaria)
}

Annotation: This paper offers a brief overview of the flint assemblages from the Neolithic period in Bulgaria (VI mill. cal BC) by following their 'evolution' that depending on the context could also be called innovation, retardation or simply modification. Some significant changes occur during the Neolithic who reflected to all aspects of the flint industry - from the raw material acquisition via techno-typological parameters until the functional connotations of different artefacts categories. The empirical corpus of the study contains assemblages coming from 18 different sites. Expectedly whatever changes are attested as occurring alongside the evolution on the Tell settlements, there is no striking rupture and discontinuity in the flint industry as claimed on the basis of fragmentary assemblages coming from other sites belonging to different cultural stages/periods of the Neolithic. The paper ends with a series of challenging questions referring to different level of our knowledge and understanding of the gradual changes of the Neolithic lifeway.

Key words: Neolithic; flint assemblages; formal toolkits; microlithization; Balkan flint

This paper offers a brief overview of the flint assemblages from the Neolithic period in Bulgaria (VI mill. cal BC) by following their 'evolution' that depending on the context could also be called innovation, retardation or simply modification. The flint assemblages have never been taken into consideration in the establishment of the prehistoric periodization in Bulagaria, that is only partially based on absolute chronology, the main method being relative synchronization of cultural events. Certain aspects of the material culture and pottery paraphernalia provoked different approaches to cultural differentiation and subdivision. The aim of this paper is to rehabilitate the chipped-stone industry into the Neolithic lifeways. The empirical corpus of the study contains assemblages coming from 18 sites (fig. 1). Most of them have been studied personally by the author and are already published $[1 ; 2 ; 3 ; 4$; $5 ; 6 ; 7]$. These assemblages, in particular the Early Neolithic ones, have been considered in a broader spatial-temporal scale and thus have been included in regional and sub-regional contexts with emphasis on various aspects as follows: i) raw material provenance and distribution $[8 ; 9 ; 10 ; 11$; 12]; ii) techno-typological features in diachronic perspective $[13 ; 14 ; 15]$; iii) functional connotation of the distinguished toolkits with trajectories to subsistence and household activities $[16 ; 17 ; 18 ; 19 ; 20]$; iv) the flint assemblages as an inherent component of the identity of first farmers and the Neolithic social dynamics $[21 ; 22 ; 23]$.

None of these aspects, however, will be discussed exhaustively. Rather a summary of the present day research will be briefly presented and commented. The studied assemblages come from different settlements - from large and well known multilayer tells as Karanovo, Azmak and Kapitan Dimitrievo; through flat sites as Slatina, Kovačevo, Yabalkovo and Harmanly; to the cemetery of Durankulak and the recently identified category of the so-called pit-sanctuaries of Sarnevo and Lyubimets $[24 ; 25]$. The excavation strategy and research design of the various sites is also very different: some of them have been submitted to long time-term planned investigations (Karanovo, Kovačevo, Drama, Slatina, Durankulak etc.), while others are the result of short salvage excavations: Harmanli, Sarnevo, Lyubimets, Ezero. The empirical dataset does not allow a relevant comparative analysis as the number of artefacts varies from 7 (Apriltsi) to 1445 (Harmanli), but their multifaceted study permits some general observations to be made about the cultural events and processes that took place in the VI mill. cal BC during the remarkable cultural development of the Neolithic period.

Chronological framework of the Neolithic

There are multiple approaches to the cultural subdivision of the Neolithic, based both on absolute and relative chronology. In the early 1960s, G. I. Georgiev offered the first chrono-cultural sequence of the Karanovo Tell and ever since, the site has become the main and irreplaceable pillar of the prehistoric cultural periodization in Bulgaria and Southeast Europe [26]. Decades later H. Todorova offered a detailed and well-argued subdivision of the Neolithic in Bulgaria by integrating different cultures and local events into a sub regional cultural block: Balkan-Anatolian cultural block/complex within which the so-called Balkan Early Neolithic (with 4 phases) and Balkan Late Neolithic (with 2 phases) are distinguished [27]. In terms of absolute chronology, the following Neolithic phases (to which all discussed sites are assigned) are more or less accepted:

- Early pottery ('monochrome' phase) - 6300/6200 $6000 / 5900$ cal BC;

- Early ('classical' phase) - 6000/5900 - 5500/5450 cal BC;

- Middle phase - 5500/5450 - 5200/5100 cal BC;

- Late phase - 5200/5100 - 4900/4850 [28].

The earliest ${ }^{14} \mathrm{C}$ date from Polianitsa-Platoto $-6420-6230$ cal BC [29] is not taken into consideration, since there is no published evidence from the site with direct concern to our topic.

Kovačevo has two early dates of $6159-5926$ cal BC and $6064-5808$ cal BC and a cluster of three date's ca $5980-5730$ cal BC [30].

Their excavators interpret two sites in northern Bulgaria as belonging to the so-called 'monochrome phase' of the Neolithic. Ohoden, near Vratsa (northwest Bulgaria) is considered to belong to a 'monochrome' (i.e. earliest) Neolithic phase on the basis of a comparative pottery study with sites of the Starčevo culture in eastern Serbia and Southwest Romania, and has a date of $5710 \pm 40$ cal BC (with details KN-5655, 6830 \pm 45 BP) [31]. This date incidentally does not fit with the claim of 'monochrome' affiliation and rather belongs to the classical early stage of the Neolithic. Some dates from Dzhuljunitsa (north central Bulgaria), according to its excavator, fall in the last two centuries of the VII millen- 
nium BC. The pottery features confirm the attribution of the site to the earliest Neolithic in Bulgaria [32]. The cluster of ${ }^{14} \mathrm{C}$ dates suggests a relatively later start of the Neolithic sequence $-c 6000$ cal BC - i. e. Synchronous with Karanovo I beginning [33].

As far as the Neolithic chronological sequence and cultural periodization are concerned, the dates from the emblematic Tell Karanovo should be pointed out. The multilevel stratigraphy of this site covers the completely prehistoric sequence (from the Early Neolithic to the Bronze Age). According to the ${ }^{14} \mathrm{C}$ dates, the following distinction has been suggested:

- Karanovo I - 6000 - 5750 cal BC;

- Karanovo II - 5750 - 5500 cal BC;

- Karanovo III - 5500 - 5280 cal BC [34].

The subsequent new excavations and detailed research on the pottery assemblages from Karanovo led to further precision of the cultural periods identified at this tell. In parallel with the Karanovo Tell stratigraphic differentiation, a concept of dynamic development of the Neolithic cultures (particularly in Thrace) has been promoted and the final scheme can be summarized as follows:

- Karanovo I culture (Early Neolithic) = Karanovo I pe$\mathrm{riod} /$ layer at the eponymous Tell;

- Karanovo II culture (Early Neolithic) = Karanovo II period/ layer;

- Protokaranovo III cultural event (Middle Neolithic) = Karanovo II-III period/ layer;

- Karanovo III culture (Late Neolithic) = Karanovo III period/ layer;

- Karanovo III-IV culture (Late Neolithic) $=$ Karanovo III-IV period/ layer;

- Karanovo IV culture (Late Neolithic) = Karanovo IV period/ layer $[35 ; 36 ; 37]$.

This too complicated cultural periodization is recently getting progressively used as a referential corpus. In terms of absolute chronology, there are no new available dates for the periods from Tell Karanovo itself, but in a broader context of Turkish Thrace, Southeast Europe end Northwest Anatolia a comparative chronology offers the following sequence of the Karanovo periods:

- Karanovo III - c 5400 - 5300 cal BC;

- Karanovo III-IV - 5300 - 5050 cal BC;

- Karanovo IV - 5050 - 4900/4800 cal BC [38].

There is obvious discrepancy of the position of post-Early Neolithic periods in the offered chronological schemes. In order to illustrate the chrono-cultural affiliation of the processes and phenomena discussed here, we will refer to the cultural periodization used in Nokolov' publications.

Neolithic flint assemblages in a diachronic perspective

The sites that are the focus of this paper have different cultural belonging. The ratio between the Early and Late Neolithic sites is $8: 8 ; 3$ sites reveal both early and late Neolithic features (fig. 1). The key site that provides the opportunity for diachronic analysis in evolutionary terms of the material culture (including flint industry) is Tell Karanovo. I was involved in the study of the flint assemblages from all layers - from the Early Neolithic to the Late Chalcolithic - that derive from excavated S and NS sectors of the site, as well as from the previously excavated trench O19 (Karanovo II-III to Karanovo IV layers) $[3 ; 4 ; 19]$. This very useful experience and accumulated observations were helpful in the subsequent work on new assemblages from various contexts. Thus, additional aspects/details of the general and evolutionary determined development of the Neolithic flint industry have become known and have contributed to a comprehensive, but ever growing, concept for the role of this industry in the past.

Raw material provenance and distribution

The raw material of the early Neolithic flint assemblages represents one of the most peculiar characteristic of these assemblages (fig. 2). Among these assemblages a significant number of artefacts (not necessarily the majority) consist of the so-called formal toolkits (vide infra). They are made of yellow-honey (waxy) coloured, white spotted high quality Самарский научный вестник. 2014. № 3(8) flint called in the literature '(Pre-) Balkan platform flint', 'Dobrudzha flint' or simply 'Balkan flint' (BF). The research conundrum of the Balkan flint inevitably attracts the attention of anyone involved in the study of the Early Neolithic in the Balkans due to its presence (in some cases massive) in early farming sites. The present author has been deeply involved in the BF research agenda and several conference presentations and papers have already been made $[10 ; 6 ; 11$, 2013). The geological aspect of the BF problem was elucidated by $\mathrm{Ch}$. Nachev who had offered an adapted map and comprehensible description of the sediment logical context of flint outcrops in Bulgaria [39; 12, fig.5 ]. According to Nachev significant accumulations of siliceous/flint concretions are located in the Moesian Platform and adjacent parts of the Balkan Alpine Orogen. Two main flint strata are considered as promising from an archaeological point of view for resolving the problem of the BF provenance: Moesian (primarily!) and Ludogorie flints. The silica concretions of the Moesian flint are hosted in the Upper Cretaceous (Campanian) chalk, chalk-like limestones and fine-grained biomorphic limestones (Maastrichtian) [12]. The consecutive collaborative pilot-studies were initiated by the author seeking for the BF identification and provenance. After the inconclusive results from the comparative thin section analyses of BF made by $\mathrm{Ch}$. Nachev and $\mathrm{M}$. Gurova, a new analytical approach was considered. A series of archaeological samples from Early Neolithic sites and geological samples from outcrops of Moesian and Ludogorie flints have been analyzed by $\mathrm{C}$. Bonsall using laser ablation inductively coupled plasma mass spectrometry (LA-ICP-MS) and electron probe micro analysis (EPMA) [9].The results were more promising but not exhaustive. The last project entitled "Prehistoric flint sourcing in NW Bulgaria and NE Serbia: Field survey and laboratory analyses" was carried out in 2011/12 with large scale survey and sampling for petrographic and chemical analyses. The region between Pleven and Nikopol was identified as the most probable BF proven acing area. The Ludogorie flint outcrops have been discarded as possible sources of BF. The possible routes of distribution of the BF nodule from the source to the rest of the Early Neolithic oikoumene, are summarized in Gurova [11], but of course a further application of GIS methods and models are required. Without a doubt one of the most crucial aspects in our search for the BF provenance, supply patterns and distribution, is the identification of the workshops of the first Balkan farmers. Apart from a couple of workshops near the BF source area (with uncertain attribution to the early Neolithic time), there is still a lack of reliable archaeological evidence. The only workshop in settlement context is identified in Slatina but unfortunately the fatal damages on flints caused by the destructive fire do not allow relevant reconstruction of workshop functioning [40; 41]. Nevertheless, the wide distribution of the BF among the Early Neolithic sites all over the Bulgarian territory is an indisputable fact, which is still awaiting a satisfactory explanation.

Another question that needs further investigation and relevant answer concerns the shift in raw material (BF) acquisition and network distribution, which took place in the beginning of the second half of VI mill. BC. After its remarkably important role in the Neolithisation process and its wide distribution in the Early Neolithic cultural complex in Southeast Europe, BF declined in use and significance in post-Early Neolithic time, most probably during the Karanovo III (III-IV?) period. According to the Bulgarian chronological framework the process of this disintegration is ca 5500-5280 cal BC [34] and can be regarded as a terminus ante quem for the significant and vital presence of formal toolkits and, ergo, for the importance and use of the BF.

Most of the Late Neolithic flint assemblages studies show a variability of raw material used for debitage and tool production. The raw materials are mainly local, coming from secondary placer deposits of siliceous rocks and allowing easy access. For the numerous sites in Thrace (located at different distance from the Maritsa tributaries) the range 
of raw materials can be associated with the Eastern Rhodope volcanic rocks, rich in jasper and chalcedony veins, which were the focus of a specialized geological-archaeological study [ $42 ; 43]$. The Maritsa River catchment basin contains alluvial-deluvial sediments with easily accessible re-deposited materials from Paleogenic flint rock masses which are widely spread in Plovdiv district and the Eastern Rhodopes. This particular gradual shift in raw material procurement and distribution strategy has an effect over the global changes that have occurred during the Middle and Late Neolithic phases and whose origin and operation principles are still unclear.

Early Neolithic flint assemblages - diagnostic features (formal toolkits)

As explained and argued in more detail in some previous works $[21 ; 22 ; 6 ; 11]$ and as it is mentioned above, the BF is attributable to a particular category of flint artefacts (constituting formal toolkit) that belong to the full Neolithic package of the Early Neolithic Karanovo I and II cultures. Previously, I have drawn attention to a broad range of problems relating to the earliest Neolithic flint tools (toolkits) from Bulgaria: i) the typological repertoire of the formal toolkits; ii) the cohesion with the white-on-red painted pottery of the Karanovo I culture; iii) their temporal and spatial distributions; iv) the technological background of the "macroblade" industry [22; 23]. The term 'formal toolkits', as defined by Andrefsky, is considered here as most appropriate and stands for: standardized form, additional effort in manufacturing, potential for resharpening, use of special raw material, advance preparation, anticipated use and transportability. The term formal toolkits is much more meaningful that the terms 'macroblades' or 'Karanovo type' blades whose recurring use is based on Gatsov's publication [44; see also 22].

These toolkits are attested in different proportion among the assemblages of the largest Neolithic Tell settlements like Karanovo, Azmak and Kapitan Dimitrievo (in Thrace), as well as from other important Early Neolithic sites (Kovačevo, Yabalkovo, Slatina, Rakitovo and Sedlare etc.) (fig. 3). Typologically, these toolkits consist mostly of medium to long (the longest are in the range of 12-15 $\mathrm{cm}$ ), regularly shaped blades, frequently with (bi-) lateral semi-abrupt retouch (from marginal to high and steep), and sometimes with rounded or pointed ends. Most of the artefacts in these toolkits possess macro- and micro-wear traces of use with predomination of the sickle inserts among the functional categories. There is also strong evidence of multiple re-sharpening and sickle re-use, which is the reason to assign to this toolkit the sickle inserts (even on unretouched blades) with visual polishes and heavily used working edges (fig. 4). From a technological point of view, this industry indicates application of indirect percussion (punch technique) with pressure flaking applied for the high and steep retouching. It must be stressed that no, or very few, cores and core-preparation debitage are attested among the assemblages. In this sense, no opportunity for any diacritic concept of 'chaîne opératoire' reconstruction is available. The complex of distinctive traits of these toolkits permits their identification as diagnostic feature/hallmark of the Early Neolithic in Bulgaria $[44 ; 13 ; 22,18,23]$. Moreover, this particular toolkit represents one of the characteristics of the supra-regional techno-complex of Karanovo I-StarčevoCriş-Körös cultural complex.

As mentioned above the formal tools (toolkits) are an inherent part of the EN assemblages and a kind of sign of affiliation/attribution to Karanovo I cultural alliance. They are most numerous and representative as series among the assemblages of Tells Karanovo and Azmak, followed by the sites of Yabalkovo, Slatina and Kovačevo (fig. 5). Normally the formal toolkits are virtually absent from the north Bulgarian early Neolithic contexts represented by the two sites assigned to the 'monochrome' phase - Ohoden and Dzhuljunitsa. Both sites have a rich flint industry with abundance of BF artefacts but without typical formal toolkits. The study of the Dzhuljunitsa flint assemblages is still 96 in progress and as a working hypothesis it was argued that this site with probably the earliest so far known Neolithic occupation (6100-6000 cal BC) was the first centre for BF acquisition, blade manufacture, consumption and distribution of BF in different forms of nodules and/or blanks. BF is attested in significant proportions among all debitage groups and even prevails among the blades. Blade production shows advanced knowledge of debit age (and particularly punch) techniques. The flint workers from Dzhuljunitsa were probably not particularly interested in formal toolkit utilisation and preferred another strategy - acquisition and distribution of the raw material (BF), through network of intra- and inter-regional exchange. The real producers of the formal tools could be the enclaves of the (pre-?)Karanovo I culture in Thrace with whom the central north Bulgarian population established contact at the time of, or rather before, whitepainted pottery was locally "invented" and largely distributed... " as a result of the need for consolidation and selfidentification of the newly formed community whose immigrants probably had come from various sites in the original Anatolian area" [45].

Apart from the formal tools the Early Neolithic flint industry offers examples of expedient production of debitage and tools made of local raw material, practice attested at Yabalkovo, Kovacevo and Sedlare. The typological repertoire beyond the formal toolkit consists of retouched blades and flakes, random endscrapers, spintered and notched pieces, truncations, simple perforators etc. In two cases (Ohoden and Kovačevo) the industry contains a series of geometric microliths. In the Kovačevo assemblage, around a dozen pieces are attested to consist of trapezes and segments the majority of which is made of dark-greyish (to black) flint of Rhodopes origin (fig. 6, 1). This is one of the very rare cases of geometric flints in the Early Neolithic strata. This tools category, together with a large number of micro piercers occur before the appearance of the formal toolkits in the Kovačevo sequence (fig. 6, 2). The exact appearance of this microlithic set is not clear from the stratigraphic evidence of the site (probably at Kovačevo Ia and Ib phases), whereas the BF toolkit is certainly attested in the later stage of Kovačevo Ic-Id [6]. The origin of the geometric microliths in Kovačevo relates to the very challenging problem of preNeolithic features/substratum alongside the fully developed Neolithic package brought by the first farmers reaching the Struma valley. The problem is waiting for further research and solution being far beyond the scope of the paper.

The second site with geometric microliths is Ohoden, where 5 trapezes and 2 segments are attested among large spectrum typological tools [46]. As mentioned above, there is an attempt to interpret this site as belonging the earliest 'monochrome' Neolithic [31]. Formally the geometrics match perfectly this intention. The problem, however, arises from the ${ }^{14} \mathrm{C}$ date of the stratum falling into the third century of the VI mill. BC which fits better to the middle of the classic phase of the Early Neolithic. Rather, the Ohoden geometrics could be related to the Late Neolithic microlithization which will be discussed below.

Late Neolithic flint assemblages: decline or continuity

The first observations and comments about the evolutionary changes in the Neolithic flint industries from western Bulgaria was made by Gatsov [44]. Based on typological parameters of different assemblages (of them 6 Early Neolithic and 4 Late Neolithic) he suggested a kind of technological degradation in flint industries due to the lack of yellow flint (i.e. BF in fact - MG) and a general discontinuity with the Early Neolithic traditions, expressed by typological changes. The reason why this raw material became inaccessible for the Late Neolithic groups is not addressed [44].

My study of the sequences from Tell Karanovo and Kapitan Dimitrievo with well presented early and late Neolithic strata led to some further precision and adjustments of the current knowledge about late Neolithic degradation in flint production. The comparative analysis between the assemblages from both tells, in addition to the data pubСамарский научный вестник. 2014. № 3(8) 
lished by Gatsov, have allowed to conclude that Kapitan Dimitrievo development shows more affiliations both diachronically and typologically with the materials from western Bulgaria [20].

It is noteworthy here the main observations made on the basis of the diachronic comparative analysis of the Karanovo Tell flint assemblages [14, figs. 1, 2]. During the Karanovo I-II periods the virtual 'chaine operatoire' was orientated towards the production of 'macroblades', consequently transformed to a formal tools, diagnostic for Karanovo I period and culture. During the next Neolithic periods, sporadically in the Karanovo III and mainly in the Karanovo IV period, changes in the technology and morphometric characteristics of the flint industries occurred; some tendency towards microlithization took place, attested by the appearance of some unique microliths: two trapezes in the Karanovo IIIIV period and one segment in the Karanovo IV period [4]. In the view of the unequivocal evidence of a new chaîne opératoire consisting of small cores for blades (bladelets), a probable technological link with the production microliths is suggested [4, taf. IX, 4]. The typological 'evolution' is expressed by the progressive decrease of these Karanovo I type tools, which practically existed as reminiscent forms until the Karanovo III-IV period (fig. 7). And vice versa: a progressive increase of endscrapers had started in the Karanovo IV period and reached its developed stage in the later Chalcolithic periods (Karanovo V and VI). To summarize - detectable and consecutive changes have led to smooth modification in raw material supply strategy, technology and typological repertoire.

The observations formulated above have various explanatory projections: i) the assemblages from the Tell sites were submitted to the same cultural periodization and their comparison is more adequate whereas (western Bulgarian sites were classified according to the classic Georgiev's concept); ii) the lifeways on flat sites (the majority of western settlements) significantly differ from the settlement patterns, social organization and dynamics on the Tell sites in Thrace (Karanovo and Azmak); iii) the subsistence strategy and decision-making of different Neolithic groups responds to different factors and challenges (paleoenvironmental and social); iv) even in conditions of continuous lifestyle development, some traditions and/or innovations in technology (chaîne opératoire) unavoidably have led to know-how changes and adaptations; v) whatever changes are attested as occurring alongside the evolution on the Tell settlements, there is no striking rupture and discontinuity in the flint industry as claimed on the basis of fragmentary assemblages coming from different sites belonging to different cultural stages/periods of the Neolithic.

Let us now turn to the other sites that are subject of this paper. How do the diachronic evolutionary observations listed above deal with the data from other sites on the map? Which features of the flint industries gain importance and become diagnostic during the Late Neolithic? Current observations and assessments have been mentioned that had been formulated during my studies of various Late Neolithic collections [47]. In general they can be summarized as the following significant characteristics: i) arising role of flake debitage and subsequent transformation to tools (mainly endscrapers) on flakes; ii) continuous but decreasing blade production and use with prevalence of simple retouched blades; iii) large diversity of endscrapers both in typological and morphometrical parameters, but with obvious shortening of proportions and increasing shape variety; iv) the microlithization is represented by micro core for blade (bladelets) and two categories of artefacts: (very) small endscrapers on flakes with oval (semicircular) shape and geometric microlliths sensu strico (trapezes, segments and pentagrams. The microlithization has been stated as a diagnostic feature of the late Neolithic industries $[13 ; 15]$. Some of these observation and statements will be better illustrated below using concrete case studies.

Apart from the Tells discussed above, the multilayer site of Balgarchevo in Southwest Bulgaria has an assemblage with both early and late Neolithic artefacts and the mixed character of the industry is obvious in the co-existence of formal tools with simple retouched blades and various endscrapers (including small on flakes) (fig. 9, 3).

The site of Apriltsi belongs to Karanovo III and IV periods. The flint assemblage is very scarce but significant: there are 4 artefacts of BF and 3 formal tools, suggesting affiliation with the counterpart periods of the Tell Karanovo or at least its cultural alliance (fig. 9, 1).

- As for the new and diagnostic Late Neolithic flint tools, it is noteworthy some main observations on the material from the site of Harmanli. It belongs to Karanovo IV period [48] and offers extremely rich flint assemblage which is very significant for the Late Neolithic flint industry. The industry is based on flakes with enough recognizable chaîne opératoire based on local raw materials and small size cores for blades and flakes [5, figs. 8-10]. The typological repertoire has well-defined characteristics of Late Neolithic assemblage: prevalence of small size endscrapers (including those on flakes), high percentage of retouched blades, three geometric microliths (including a pentagram) and individual reminiscent forms of Early Neolithic formal tools, which sporadic appearance is rather atypical than inherently linked with the assemblage as a whole (fig. 8). The more plausible explanation lies in the random introduction of these tools into the assemblage from the remains of the Early Neolithic sites in the region.

- As far as the geometric microliths are concerned, they appear in different late Neolithic context as follows: Tell settlements - Karanovo, Drama-Gerena; flat sites - Harmanli, Ussoe I; cemetery - Durankulak (Hamangia culture phases I-II); pit structures (Ezero, Sarnevo and Lyubimets). The most representative collection of geometric microliths (24 ex.) is known from Drama-Gerena (fig. 10, 1). Their appearance in the Late Neolithic is well argued by Lihardus as "... much more a response to a specific function or activity than a result of certain cultural scheme or tradition" [30]. In contrast to this interpretation, the geometrics from Durankulak cemetery are defined by Sirakov as points of Vielle type and are viewed as arguments for the presence of a local Mesolithic substratum that had participated in the Balkan Neolithiszation [49].The sites containing pit structures (Ezero, Sarnevo and Lyubimets) are interpreted recently as Neolithic complexes with dig-out features or pit sanctuaries [25]. My study of the flint assemblages of two of these sites - Ezero (fig. 9, 2) [50] and Sarnevo (Бъчваров и др. 2009; Gurova forthcoming) does not stimulate me to embrace such an interpretation, but more relevant conclusions should be drawn after the publication of the sites. Lyubimets is a very interesting site containing a large collection of flint artefacts (more than 10000) belonging to the Late Neolithic - Karanovo III-IV and IV periods. Apart from 14 geometric microliths (fig. 10,2) there are micro cores, small endscrapers, a splintered piece, etc. [24].

- The site of Ussoe I should be underlined as a typical example of the late Neolithic flint assemblage. It is located to the Northeast of Thrace and does not belong to its cultural background. The assemblages are studied and published by both Gatsov and Skakun $[51 ; 52]$. The site is defined as belonging to the complex of Vinča type cultures and could be synchronized with Kaloyanovets (Karanovo IV) in Thrace [27]. The flint assemblage is extremely numerous (ca. 20000 artefacts) with significant prevalence of flakes and a rich repertoire of endscrapers (including regular, fan-like, semicircular etc.). Apart from the dominating endscrapers that represent more than half of all the tools, there are retouched blades and flakes, perforators/borers, notches and geometric microliths [51рис. $2,3,12]$. The particularities of this assemblage and the striking dominance of endscrapers provoked a special study by Tsonev [53], who subsequently enlarged the technological aspects of his study including assemblages from Central North Bulgaria pointing the similarity between the assemblages of Ussoe I and Kachitsa - Late Neolithic stratum [54] 
Functional connotation of the Neolithic flint assemblages

There is no need to argue for the importance of use-wear analyses in determining the functions of prehistoric artefacts and in revealing the functional aspects/characteristics of the assemblages as a whole. A short synopsis of the results of the specialized ivestigation will be offered here. The first real usewear study of Neolithic flint assemblages was done by the Russian specialist N. Skakun on the assemblages from western Bulgaria [55] and the early Neolithic site of Slatina [41]. Later, the assemblage from Ussoe I was published as well [51]. Skakun's works reveal an exhaustive range of subsistence and household activities of the Neolithic groups from the very beginning of the first farming occupation: agriculture, stock-breading, wood, bone, stone processing etc. [55].

The succession of functional studies was continued by my research, that combines techno-typological approach with usewear analysis of the artefacts $[2 ; 3 ; 4 ; 18 ; 14 ; 19 ; 20 ; 5$; forthcoming]. There is no way to make a relevant comparison either diachronic or synchronic between the assemblages because they are too different in quantity, preservation and representatively As far as the transition between the Early and Late Neolithic strata in Tell Karanovo sequence is concerned, the observations and conclusions could be summarized as follows:

The first and main conclusion is that during the entire sequence the typological tools have prevailed. Particularly heavy use is attested among the formal toolkits. Their re-sharpening and reuse is a common observation. This process often led to an exhaustive stage of their morphology when they became too narrow or with too steep working edges (with obtuse angle) preventing any further use;

- No 'excessive' preference or need for usage of some special tool types for some specific functions has been proved. The highest use frequency is attributed to retouched blades, followed by perforators, truncations and end-scrapers. Most multi-functional were the retouched blades, which is not surprising but rather an ordinary situation. However, it must be stressed that despite the evidently increased number of endscrapers in the Late Neolithic their utilization is moderate in comparison to the other tools. It is also interesting to note that their use varied substantially and was not at all limited to the usually presumed hide processing functions. The exotic and extremely rare geometric microliths are presumably linked to the projectile points function but there are not enough diagnostic micro-wear traces for that. The only certain function for one of the trapeziums was as a sickle inserts;

- The morphological and typological spectrum of the used toolkits varies diachronically. The sickle inserts, for example, are predominantly typological tools (as compared to the nonretouched blades) throughout the Neolithic sequence but in the later periods more typological categories refer to this function (apart from formal toolkit, there are other retouched and truncated blades, end-scrapers etc.). It should be stressed however that almost all sickle inserts have oblique polish/working parts which suggests that the traditional and well known Neolithic 'Karanovo type' sickle continues to be the main agricultural instrument (fig. 4).

- The distribution of the worked materials reveals a slight domination of plants (including cereals) and wood, reflecting the main subsistence activity carried out by the Tell inhabitants. However, the primary role of agriculture among the subsistence activities should be underlined [18].

The listed observations are valid for all assemblages in south Bulgaria, with some unavoidable variations. This conclusion contradicts Skakun' results about the Ussoe I assemblages. Her statistics shows a predominance of tools used in processing of secondary animal products [51]. Unfortunately, it is difficult to distinguish the functions in relation to typology among the 19 functional categories. Presumably some of these categories were used in hunting and the geometric microliths are the best solution.

\section{Discussion}

There is certainly some discrepancy in terms, observations and conclusions when considering the evolutionary development of each element of the material culture. The flint industries represent one of the most conservative features of the prehistoric materiality (particularly in comparison with pottery) and challenge their researchers with a series of questions.

Challenging questions can be formulated on different levels: What is the origin of these industries? To what influences (and from where) were they subjected during their evolution? What zones of cultural interactions can they be associated with? To what extent do they reveal and represent certain traditions and innovations in material culture? To what degree do they respond to palaeoenvironmental and social conditions and need? ....etc., etc.

One of the most important and still enigmatic problems refers to the origin of the early Neolithic formal toolkits (or 'macroblades'). This industry is still conceived as "... one of the most puzzling questions of the Balkan pottery Neolithic" [56]. It is stimulating, but not realistic, to expect to find a direct connection between the macroblade industry from the Balkans and some desirable Anatolian "homeland" area. In combination with the emblematic and slowly advancing 'Balkan flint' problem, the phenomenon of the early Neolithic formal toolkits remains a challenge.

There is no satisfactory explanation of the big changes taking place during the Middle and Late Neolithic phases in the second half of VI mill. BC. The transformations concern every aspect of material culture and indicate some serious demographic and social processes which remain still unclear. Probably the strongest evidence for the changes came from the new pottery (black-burnished), occurring in the middle of the VI mill. BC and defined as Karanovo III culture in Thrace [35]. The changes are thought in the context of migrations and multidirectional cultural influences, but the problem is still unresolved. Insufficiently involved into explanatory models are the data and interpretation of the multidisciplinary research exploring palaeoenvironmental conditions.

Within the range of functional studies and problems various challenges should be listed: from the very banal and unresolved questions about the creation of a functional typology, through the disproportion between the mass of finished tools and the restricted range of their utilization, to the functions of particular categories gaining importance dring the Late Neolithic as micro endscrapers and microliths. There are important questions demanding further investigations and answers such as: i) what were the priorities of the ancient flint craftsmen: trade demands, concrete functional needs, formal typological representativity or some raw materials supply restrictions?; ii) to what extent the link typology/function is preconditioned, or not, by settlement particularities and intersite contacts, etc.?

I tried to present different interpretative issues in investigating different flint assemblages from the same perspective - their evolution ... whatever that could mean... The Neolithic Tells displays a various representations of continuative changes (modifications, innovations, retardations etc.) alongside the cultural process. Flint assemblages coming from single layer sites could differ strikingly to each other even belonging to some cultural period, just because they come from different context and could represent a peculiar local variant (facies) of a known culture. On the other hand, the questions arising are unavoidable and demanding...

Acknowledgment

I should like to express my gratitude to Dr B. Gaydarska for her reading of the paper and suggesting improvements to the English.

\section{REFERENCES}

1. Гацов, И., Гюрова, М. Изследване на кремъчни артефакти от раннонеолитния пласт на Азмашката селищна могила край Стара Загора // Известия на музеите от Югоизточна България. XIX, 1998. 7-20.

2. Гюрова, М. Функционален анализ на кремъчен ансамбъл от селищна могила Капитан Димитриево// Археология. 2001. 3-4, 38-47 
3. Gürova, M. Gebrauchsspurenanalyse des neolithischen Feuersteininventars. In Hiller, S., Nikolov, V. (Hrsg.). Karanovo, I, Die Ausgrabungen im Südsektor 1984-1992, Salzburg-Sofia: Verlag Ferdinand Berger \& Söhne, Horn/ Wien.1997. $363-375$.

4. Gürova, M. Feursteininventar aus Sondage O 19 in Tell Karanovo: typologische und funktionale Analyse. In Hiller, S., Nikolov, V. (Hrsg.). Karanovo, II, De Ausgrabungen in O19. Wien.2002a. 149-175.

5. Gurova, M. Chipped-stone assemblage from the prehistoric site at Harmanli. - Studia Praehistorica 13, 2010 169-195.

6. Gurova, M. Early Neolithic site of Kovačevo: A case study of 'Balkan Flint' formal toolkit. - Studia Preahistorica 14, 2011b. 71-81

7. Terziiska-Ignatova, S., Gurova, M. Finds from the Neolithic settlements Apriltsi//East and West. Culture and Civilization at the Lower Danube. Călăraşi: Editura DAIM, 2011. 49-58

8. Гюрова, М, Иванова, С., Андреева, П., Павликовски, М. Издирване на археологически обекти в област Плевен. - Археологически открития и разкопки през 2011 г. София. 2012. 510-513.

9. Bonsall, C., Gurova, M., Hayward, C., Nachev, Ch., Pearce, N.J.G. Characterization of 'Balkan flint' artefacts from Bulgaria and the Iron Gates using LA-ICP-MS and EPMA. //Интердисциплинарни изследвания, XXIIXXIII. 2010. 9-18.

10. Gurova, M. Prehistoric Flint Assemblages from Bulgaria: A Raw Material Perspective//East and West. Culture and Civilization at the Lower Danube. Călăraşi: Editura DAIM, 2011a 96-115.

11. Gurova, M. 'Balkan Flint' - fiction and/or trajectory to Neolithization: Evidence from Bulgaria. - Be-JA, 2/1. 2012b. 15-49.

12. Gurova, M., Nachev, Ch. Formal Early Neolithic Flint Toolkits: Archaeological and Sedimentological Aspects// Geoarchaeology and Archaeomineralogy. Proceedings of the International Conference, 29-30 October 2008 Sofia. Sofia, 2008. 29-35.

13. Гюрова, М. 2005. Кремъчните артефакти в контекста на диагностичните находки. - Годишник на Департамент Археология, НБУ, VI, 88-103.

14. Gurova, M. Evolution and Retardation: Flint Assemblages from Tell Karanovo//Prehistoric Thrace, Sofia-Stara Zagora, 2004b. 244-253.

15. Gurova, M. Outillages lithiques préhistoriques de la Bulgarie et le problème de 'fossiles directeurs'//La préhistoire du Sud-Est Européen : traditions et innovations. (Etudes balkaniques 15). Paris: De Boccard, 2008b.161-175.

16.Гюрова, М. Праисторическите земеделски сечива - индикатори на неолитизационния процес// Праисторически открития в България: Новите предизвикателста. София, 2008. 39-55.

17.Gurova, M. Mobilier en silex de la nécropole Dourankulak - analyse fonctionnelle// Durankulak, Band. II, Teil 1, Die prähistorischen Gräberfelder von Duranlkulak. Sofia, 2002b. 247-256.

18.Gurova, M. Outils agricoles des assemblages néolithiques en silex de la Bulgarie - un contexte plus large. BAR International Series 1303. Oxford, 2004a. 37-51.

19.Gurova, M. Feuersteinartefakte. Functionanalyse// Karanovo IV, Die Ausgrabungen im Nordsüd-Schnitt, 1993-1999. Wien, 387-409, Taf. 2005. 215-220.

20. Gurova, M. Functional Aspects of the Early Neolithic Flint Assemblages from Bulgaria and NW Anatolia// Aegean - Marmara - Black Sea: the Present State of Research on the Early Neolithic. Langenweissbach 2006.157-175.

21. Гюрова, М. Кремъчният фактор в неолитизационния дебат//LAUREA. In honorem Margaritae Vaklinova (Книга II). София. 2009. 1-14.

22. Gurova, M. Towards an understanding of Early Neolithic populations: a flint perspective from Bulgaria// Documenta Praehistorica 35,2008a. 111-129.

Самарский научный вестник. 2014. № 3(8)
23.Gurova, M. Establishing the identity of Bulgaria's first farmers - a new perspective. - Achaeologia Bulgarica, 2012a. 2, 1-26.

24. Анастасова, Е. 2012. Кремъчни артефакти с малко размери от къснонеолитно ямно светилище Любимец// Василка Герасимова-Томовd. In Memoriam. София: НАИМ-БАН. 2012.17-22.

25. Nikolov, V. A Reinterpretation of Neolithic Compelxes with Dig-out Featurs: Pit Sanctures. - Studia Praehistorica, 14. 2011. 91-119.

26. Georgiev, G.I. Kulturgruppen der Jungstein- und der Kupferzeit in der Ebene von Thrazien (Südbulgarien)// L'Europe à la fin de l'âge de la pierre. Praha. 1961.45-100.

27.Тодорова, Х., Вайсов, И.Новокаменната епоха в България (краят на седмо-шесто хилядолетие преди новата ера). София: Издателство на БАН.1993.

28.Boyadziev Y. Chronology of Prehistoric Cultures in Bulgaria// Prehistoric Bulgaria. Monographs in World Archaeology 22. Madison Wisconsin.1995. 149-191.

29.Görsdorf, J., Bojadžiev, J. Zur absoluten Chronologie der bulgarischen Urgeschichte. - Eurasia Antiqua 2. 1996. 105-173.

30.Lichardus-Itten, M., Demoule, J.-P., Pernicheva, L., Grębska-Kulova, M., Kulov, I. Kovačevo, an Early Neolithic site in South-West Bulgaria and its importance for European Neolithization// Aegean - Marmara - Black Sea: the Present State of Research on the Early Neolithic. Langenweissbach. 2006.83-94.

31.Ганецовски, Г. 2009. Оходен. Селище от ранния неолит. Разкопки 2002-2006. София: Craft House Bulgaria Ltd.

32.Elenski, N. Cultural Contacts of North-Central Bulgaria with Thrace and the Marmara Area in the Early Neolithic//Prehistoric Thrace, Sofia-Stara Zagora. 2004.7179.

33.Krauß, R., Elenski, N., Weninger, B., Clare, L., Cakırlar, C., Zidarov, P. Beginnings of the Neolithic in Southeast Europe The Early Neolithic sequence and absolute dates from Džuljunica-Smărdeš (Bulgaria). In print.

34.Görsdorf, J. C14 - Altersbestimmungen. Karanovo, I, Die Ausgrabungen im Südsektor 1984-1992, SalzburgSofia: Verlag Ferdinand Berger \& Söhne, Horn/Wien. 1997. 377-384.

35.Николов, В. Проучвания върху неолитната керамика в Тракия// Керамични комплекси Караново II-III, III и III-IV в контекста на Северозападна Анатолия и Югоизточна Европа. София: Агато. 1998.

36.Nikolov, V. The Circumpontic Cultural Zone during the Neolithic Period//Archaeologia Bulgarica, II, 2.1998. $1-9$.

37.Nikolov, V. Dinamics of the Cultural Processes in Neolithic Thrace // Prehistoric Thrace. Sofia-Stara Zagora. 2004. 18-25.

38. Parzinger, H. Die mittel und spätneolitische Keramik aus Aşaği Pınar, Grabungen 1993-1998 // Aşaği Pınar II. Die mittel- und spätneolitische Keramik. Archäologie in Eurasien, 18.2005. 1-245.

39.Начев, Ч. Основните типове флинт в България като суровини за направа на артефакти // Интердисциплинарни изследвания XX-XXI.2009. 7-21.

40.Гацов, И. Кремъчен ансамбъл от работилницата // Раннонеолитно жилище от Слатина, София. Разкопки и проучвания. София, 1992. 99-101.

41.Скакун, Н. Типолого-трасологически анализ на оръдията на труда от жилищното помещение // Раннонеолитно жилище от Слатина, София. Разкопки и проучвания. София, 1992. 101-107.

42. Кънчев, К.,Начев, И., Ковнурко, Г. Кремъчнитескели в България и тяхната експлоатация//Интердисциплинарни изследвания, VII-VIII, 1981. 41-56.

43.Начев, И., Кънчев, К. Палеогенските кремъчни скали в Родопите // Интердисциплинарни изследвания, XVII, 1990. 25-30.

44.Gatsov, I. Neolithic Chipped Stone Industries in Western Bulgaria. Kraków: Jagellonian University Press. 1993. 
45.Nikolov, V. Problems of the early stages of the Neolithization in the southeast Balkans// A short walk through the Balkans: the first farmers of the Carpathian basin and adjacent regions. Quaderno 12, 2007. 183-188.

46.Zlateva-Uzunova, R. Early Neolithic Stone Assemblage from Ohoden-Valoga Site, Building N 1// Ohoden: an Early Neolithic site, excavations 2002-2006, Sofia: BG Print, 2009. 63-75.

47.Gurova, M. (forthcoming). Flint assemblages from Sarnevo. In Sarnevo: Ritual complexes from the Late Neolithic, Iron Age and Roman period. Sofia, 45 p., 17 figs. 48.Бъчваров, К., Божилов, В., Петрова, В. Археологически разкопки на къснонеолитно селище при Харманли//Археологически открития и разкопки през 2004 г. София, 2005. 43-44.

49.Sirakov, N. Flint artifacts in prehistoric grave-good assemblages from the Durankulak cemetery// Durankulak, Band. II, Teil 1, Die prähistorischen Gräberfelder von Duranlkulak. Sofia, 2002. 213-247.

50. Сотиров, И., Стефанова,Т., Гатев, П., Гюрова, М. Спасителни проучвания край с. Езеро, Новозагорско, Обект 3, КМ 244+900 - 245+300, ЛОТ 3 по трасето на АМ „Тракия”//Археологически открития и разкопки през 2009 г. София.2010. 52-54.

51.Скакун, Н. Результаты исследования производственного инвентаря неолитического поселения Усое I (Болгария) // Экспериментально-трасологические исследования в археологии. Санкт-Петербург, 1994. С.85-118.

52.Gatsov, I. Le site néolithique d'Oussoe, département de Varna. Répartition du matériel en silex par tranchées de fondation. Caractéristiques et comparaisons des artefacts// Studia Praehistorica, 10, 1990. 91-102.

53. Tsonev, Ts. Neolithic end-scrpaper varialibility of northeast Bulgaria. - Sprawozdania Archaeologiczne, XLII, 1990. 333-345.

54. Цонев, Ц. Техники на обработка на кремъка и палеосреда от Централна Северна България. София: НАИМ-БАН. 2007.

55. Skakun, N. Results of traseological examination of flint implements from Neolithic settlements in Western Bulgaria// Neolithic Chipped Stone Industries in Western Bulgaria. Kraków: Jagellonian University Press, 1993. 52-54.

56. Kozłowski, J.K. Western Anatolia, the Aegean Basin and the Balkans in the Neolithisation of Europe//A short walk through the Balkans: the first farmers of the Carpathian basin and adjacent regions. Quaderno 12, 2007. 39-52.

\section{FIGURE CAPTIONS}

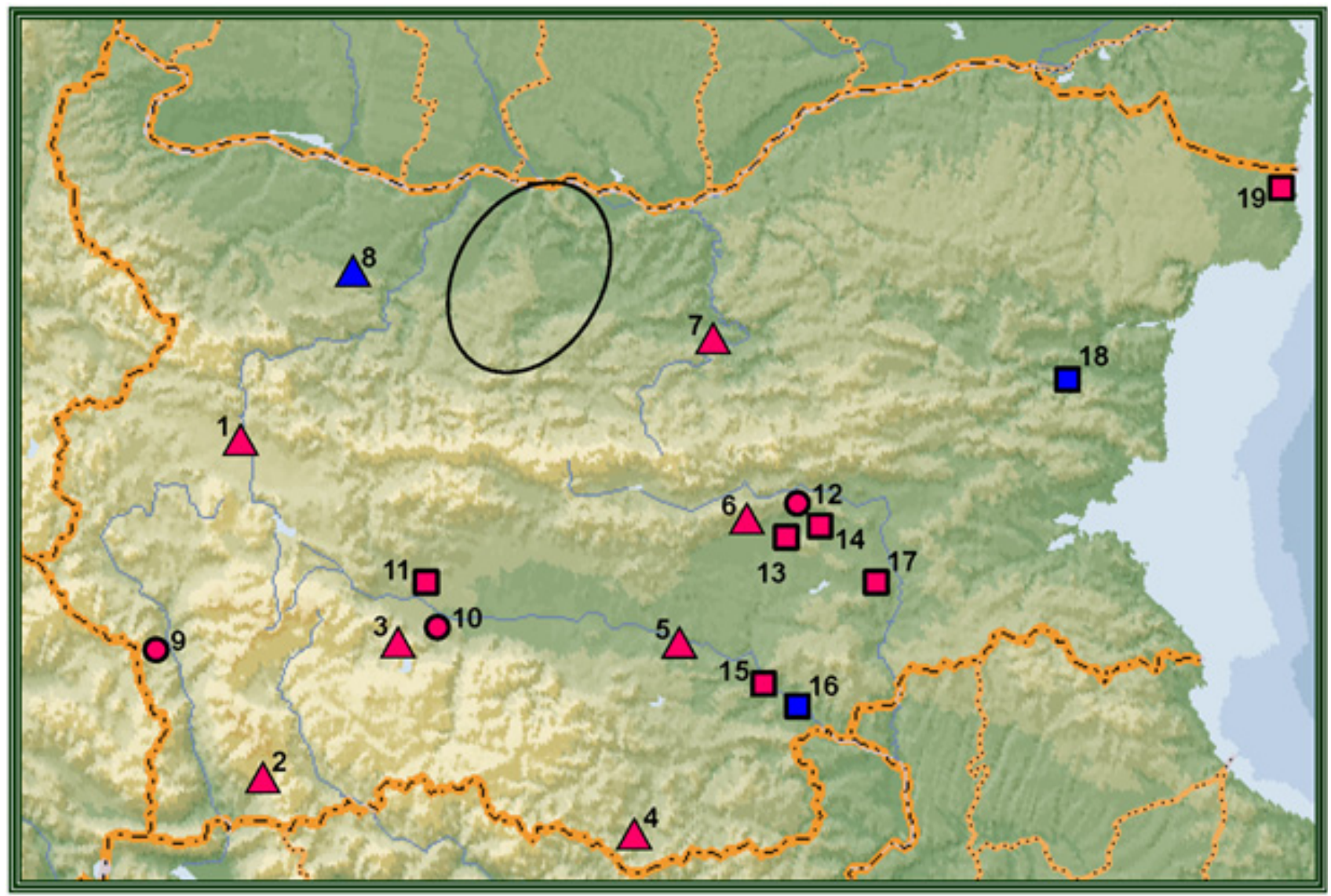

Fig. 1. Map of Bulgaria with sites mentioned in the text: 1 -Slatina-Sofia; 2 - Kovačevo; 3 -Rakitovo; 4 -Sedlare; 5-Yabalkovo; 6-Azmak; 7 -Dzhuljunitsa; 8 -Ohoden; 9 -Balgarchevo; 10 - Kapitan Dimitrievo; 11 - Apriltsi; 12 - Karanovo; 13 - Sarnevo; 14 -Ezero; 15 -Harmanli; 16 -Lyubimets; 17 -Drama-Gerena; 18 - Ussoe I; 19 Durankulak. Legend: triangle - Early Neolithic site; circle - Early and Late Neolithic site; square - Late Neolithic site; pink - site' assemblage studies by the author; bleu - site' assemblage used by publication. The zone rich of Balkan flint outcrops is marked in black. Figure by M. Gurova. 

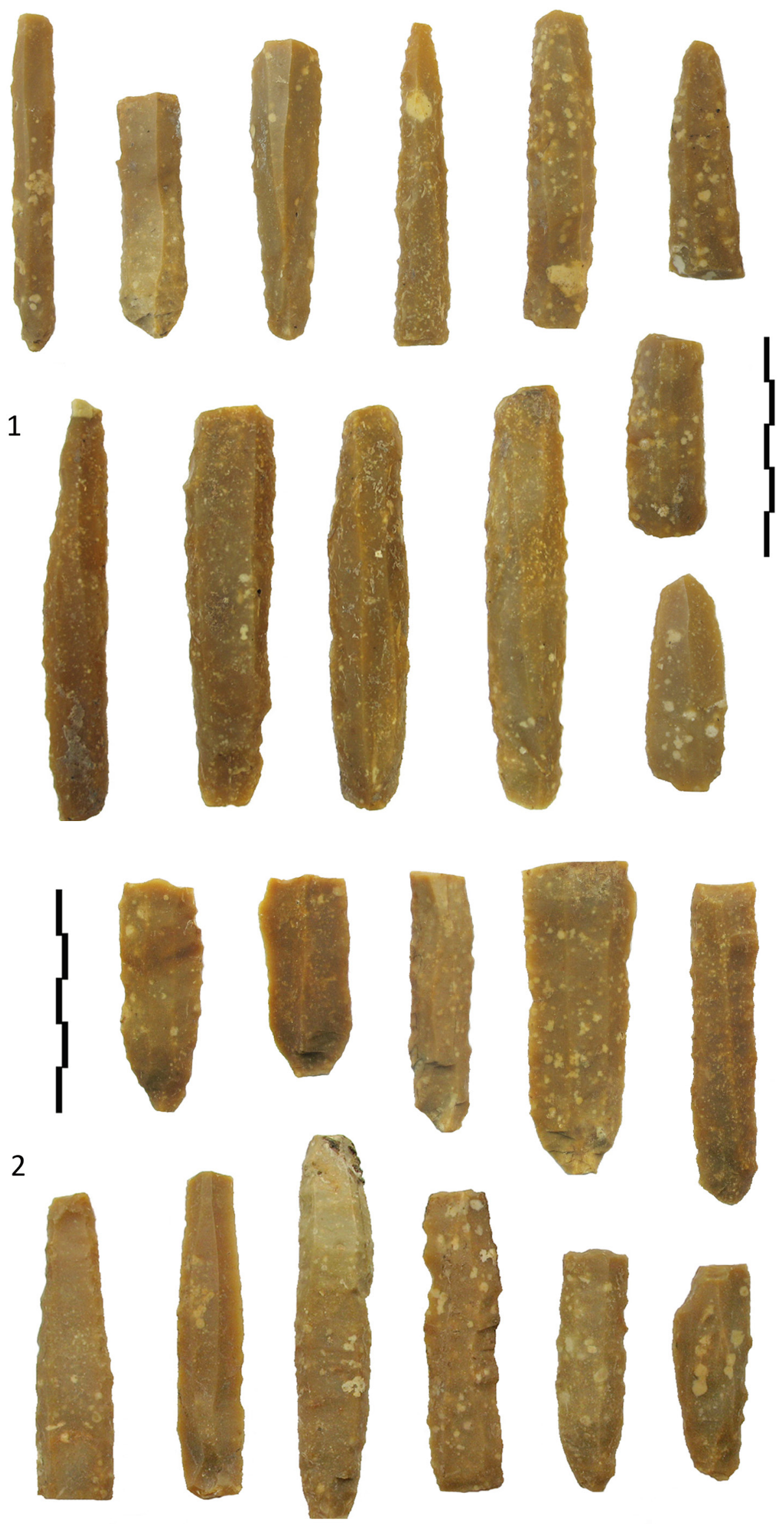

Fig. 2. Early Neolithic flint artefacts (formal toolkit) made of 'Balkan flint' from the sites: 1 - Yabalkovo; 2 Slatina. Photo by M. Gurova. 

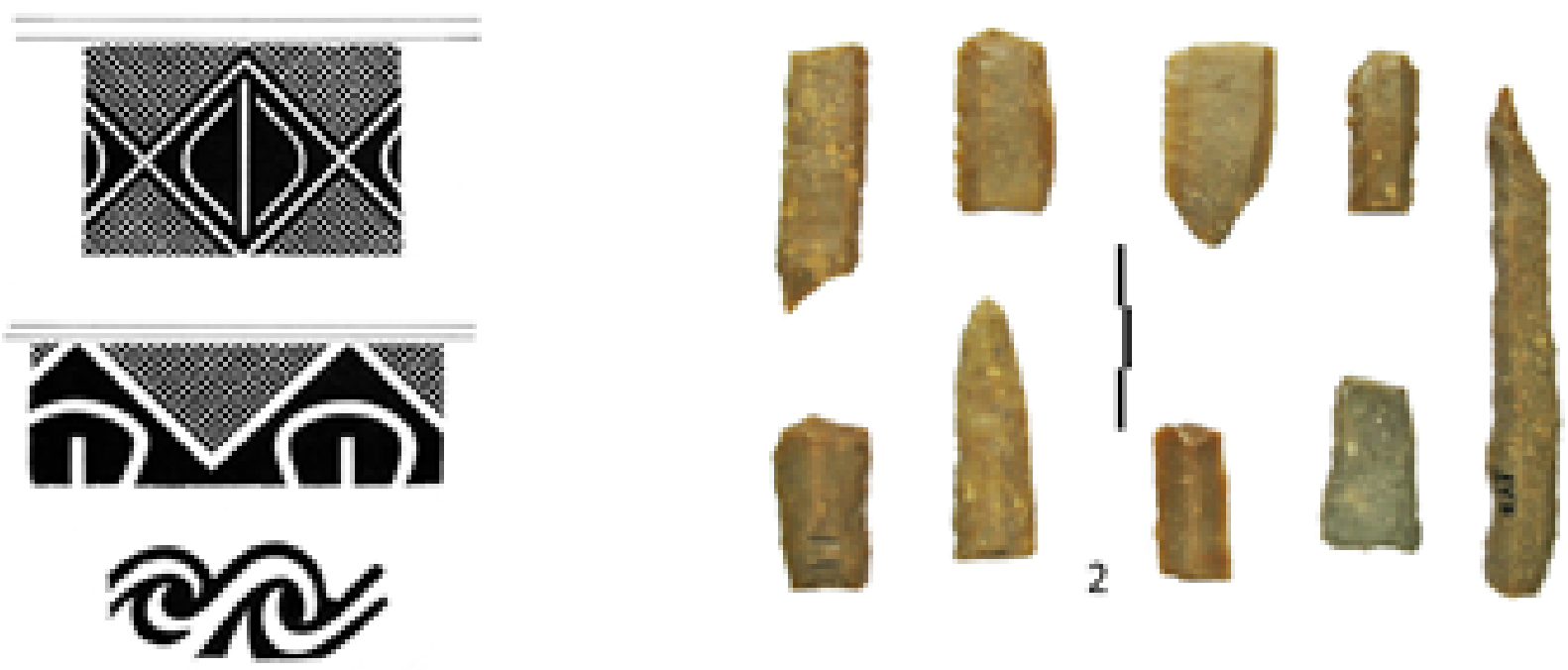

A

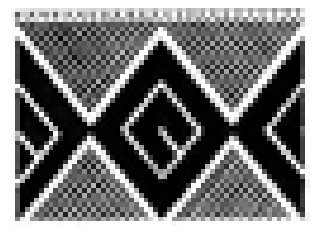

1
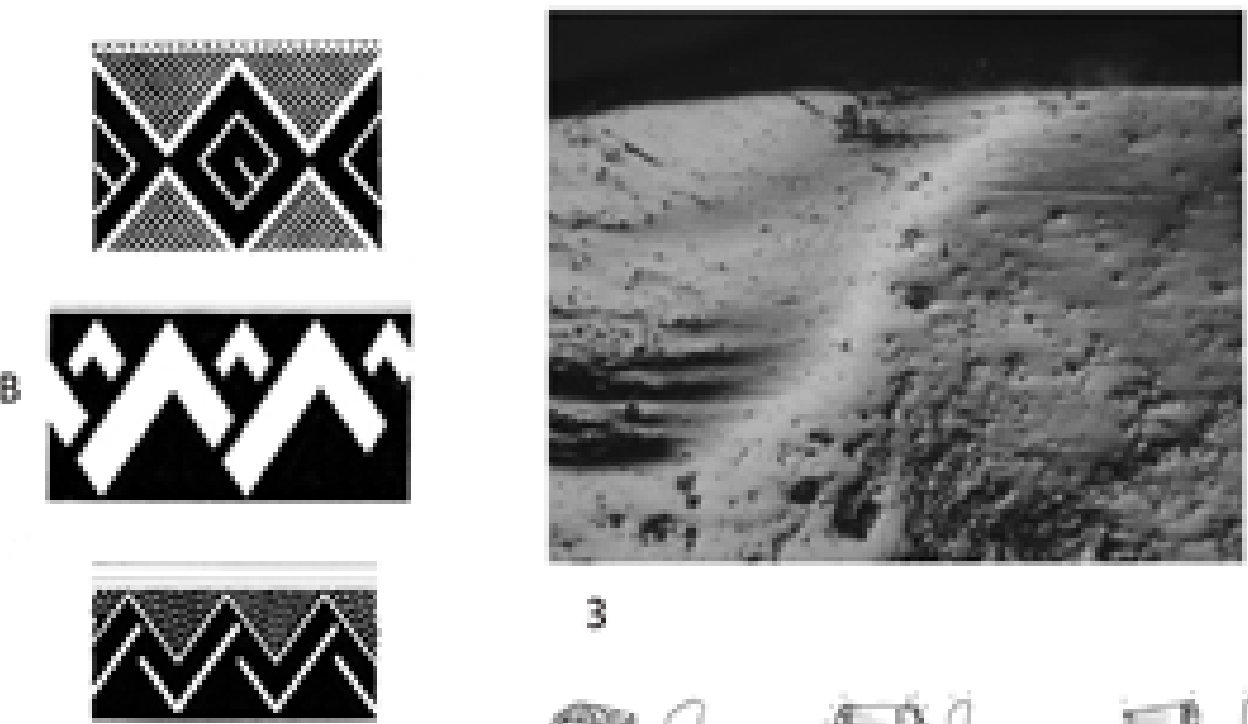

3
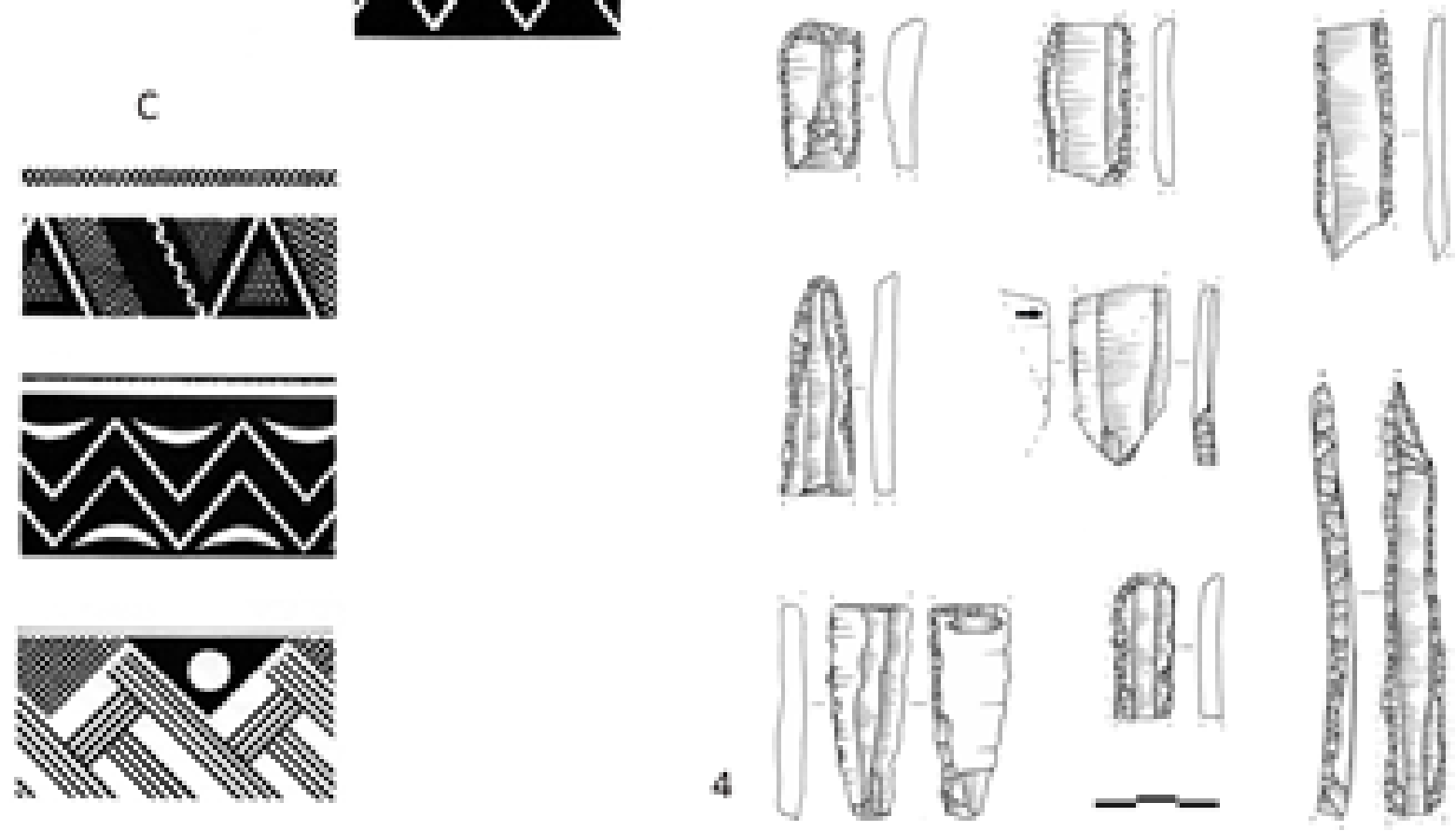

Fig. 3. Early Neolithic site of Rakitovo: 1 - white-painted pottery decoration: A-Rakitovo style; $B$ - mixed style; C-Thracian style (according to A. Raduncheva et al. 2002, figs. 86-88); 2 -formal flint toolkit; 3 - microphotograph of the cereal polish (x 100), the artefact' place is fixed by arrow on the drawing bellow; 4 - flint artefacts (tools). Figure by M. Gurova. 

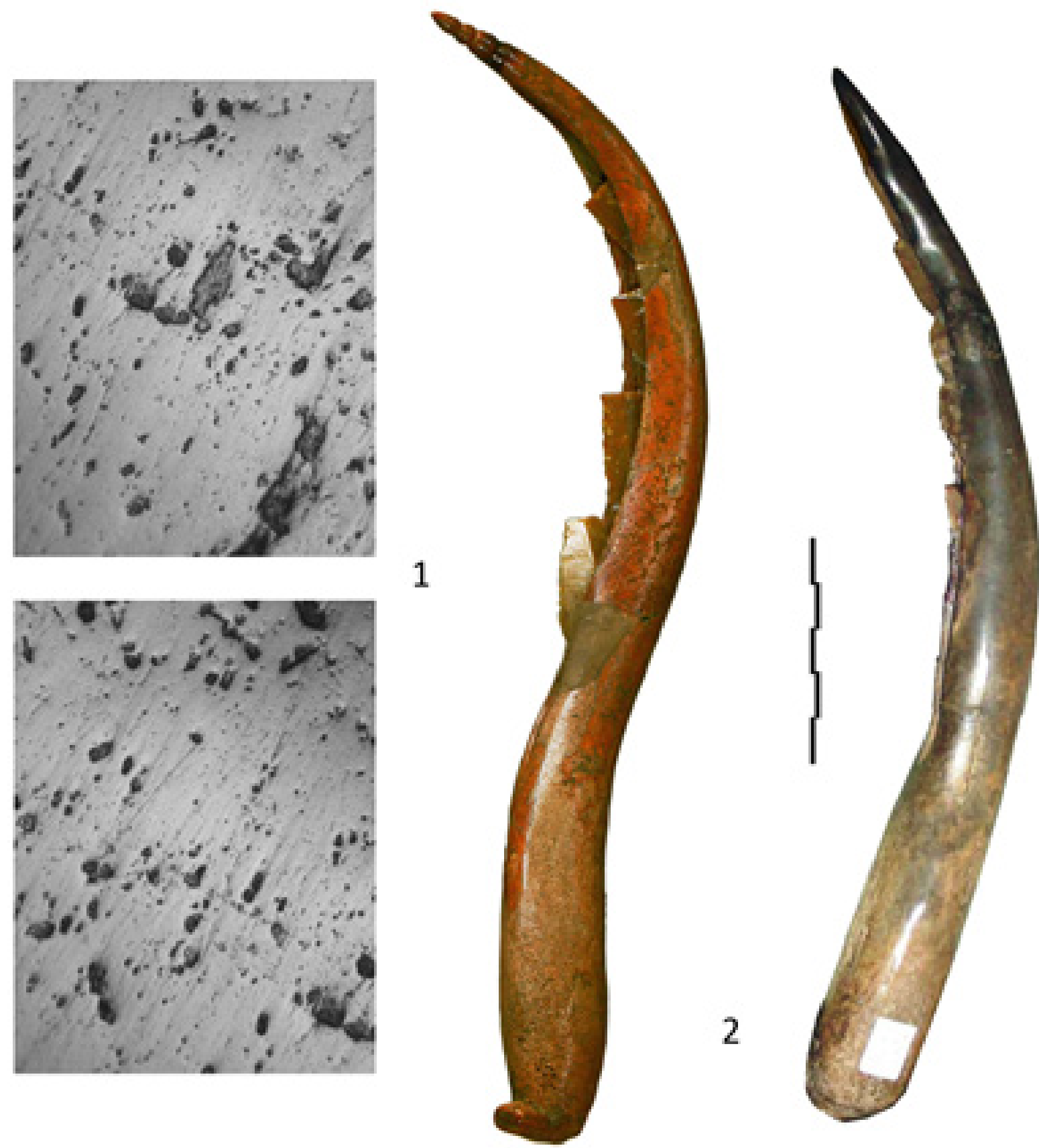

1 


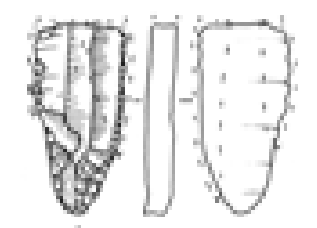

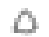

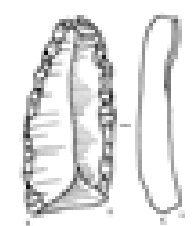

(7) 013
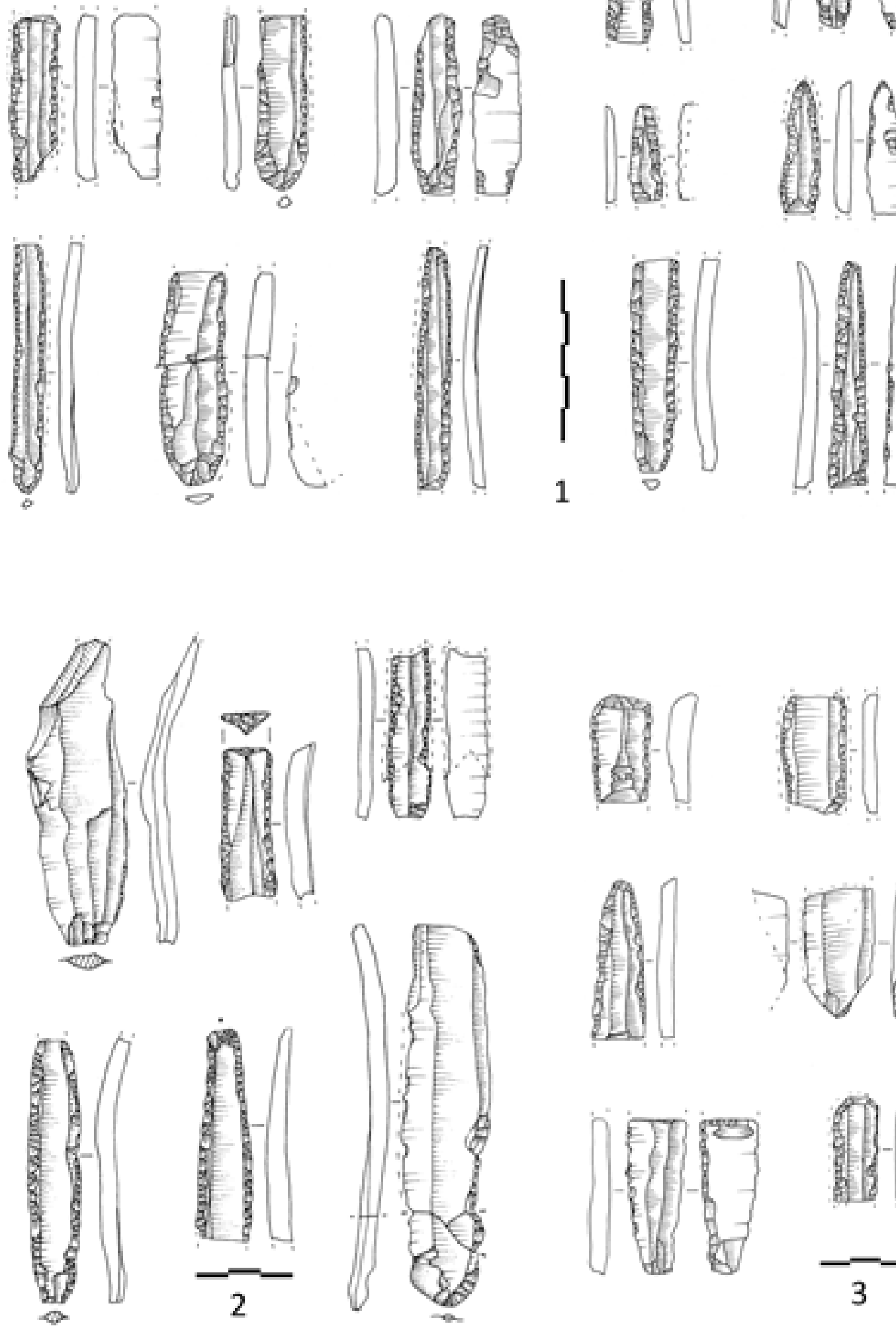
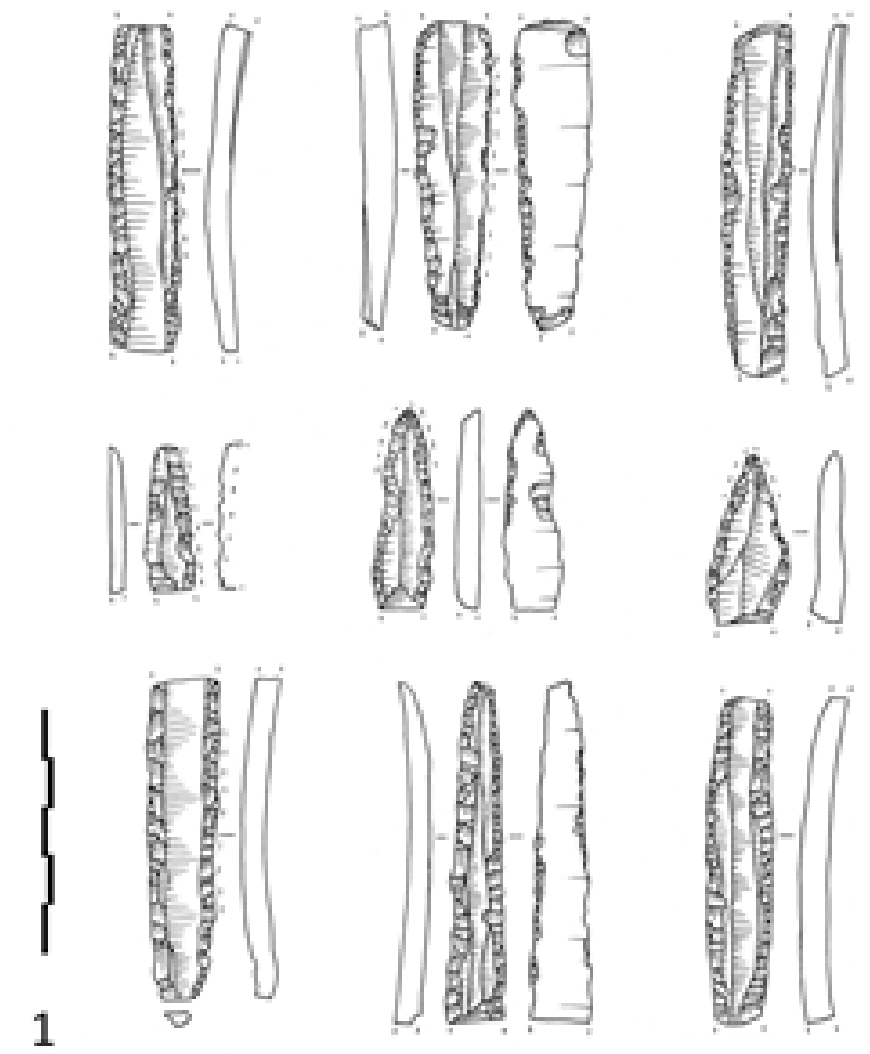

Fig. 5. Typological features of Early Neolithic flint assemblages (and prticularly formal toolkits)from the sites: 1-Yabalkovo; 2 - Slatina; 3 - Rakitovo. Drawings by M. Gurova. 

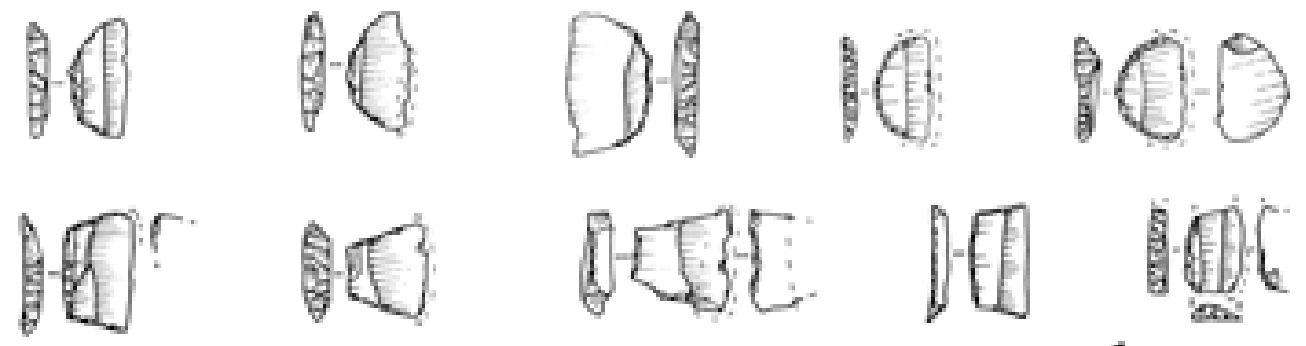

1
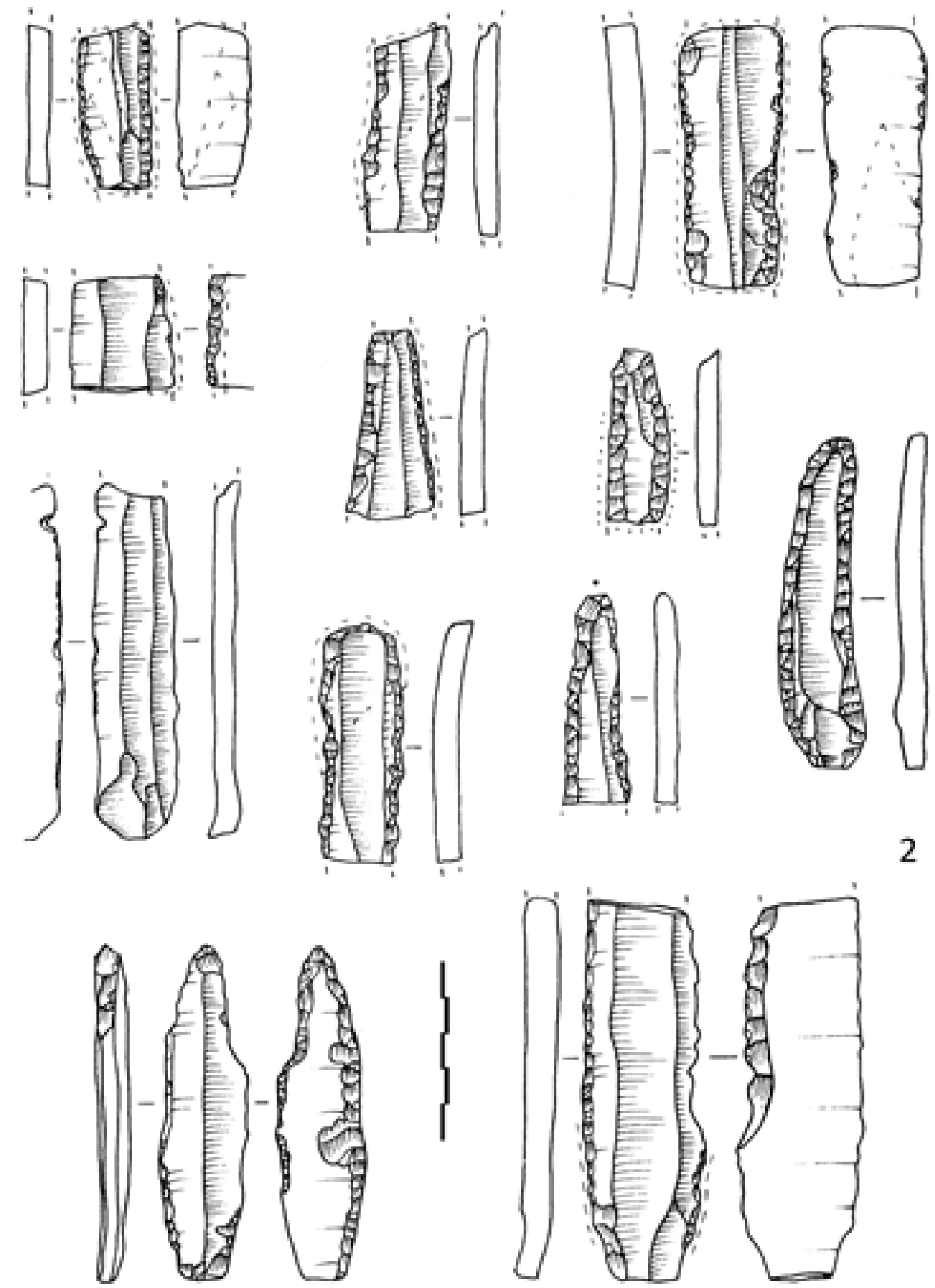

Fig. 6. Early Neolithic artefacts from the site of Kovačevo: 1 -geomethic microliths; 2 -formal tools of 'Balkan flint'. Drawings by M. Gurova. 

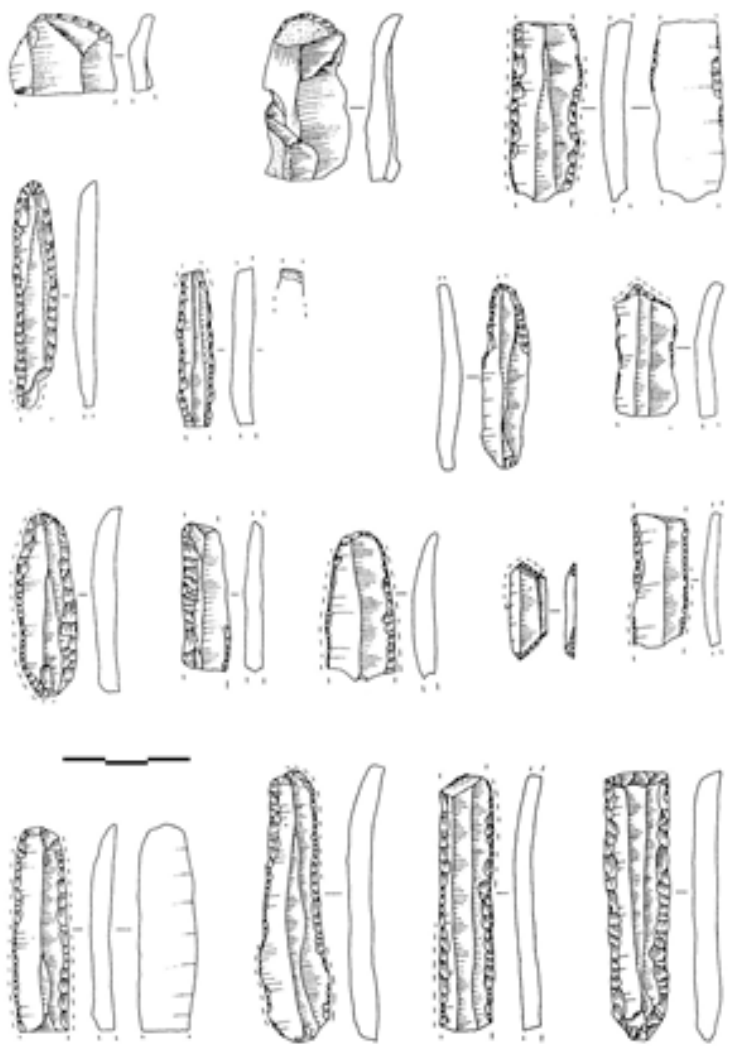

Fig. 7. Late Neolithic flint assemblage from Tell Karanovo, period III-IV, trench O19. Drawings by M. Gurova.
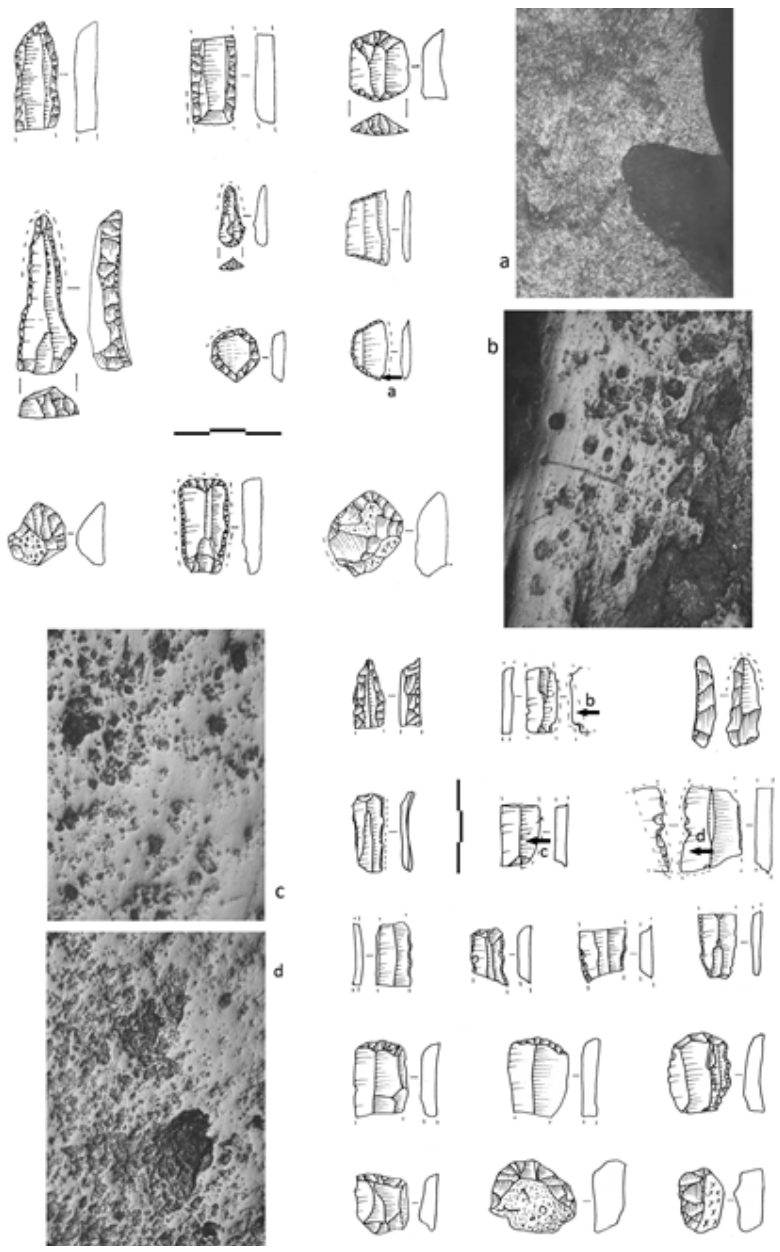

Fig. 8. Late Neolithic flint assemblage from the site of Harmanli (Karanovo IV period) and microphotographs of usewear tarces (x 100). Drawings and photo by M. Gurova. 


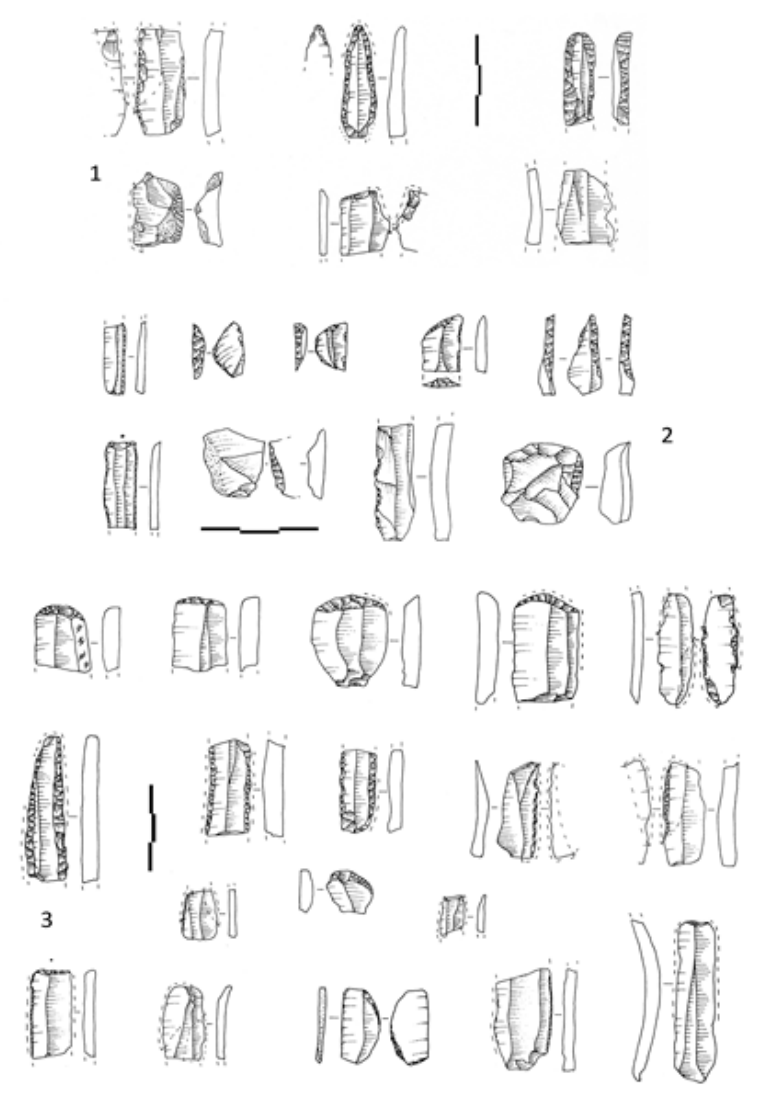

Fig. 9. Late Neolithic flint assemblages from the following sites: 1 - Apriltsi (Karanovo III and IV); 2 - Ezero (Drianova Tell - Karanovo IV); 3 - Balgarchevo (Karanovo II and III). Drawings by M. Gurova

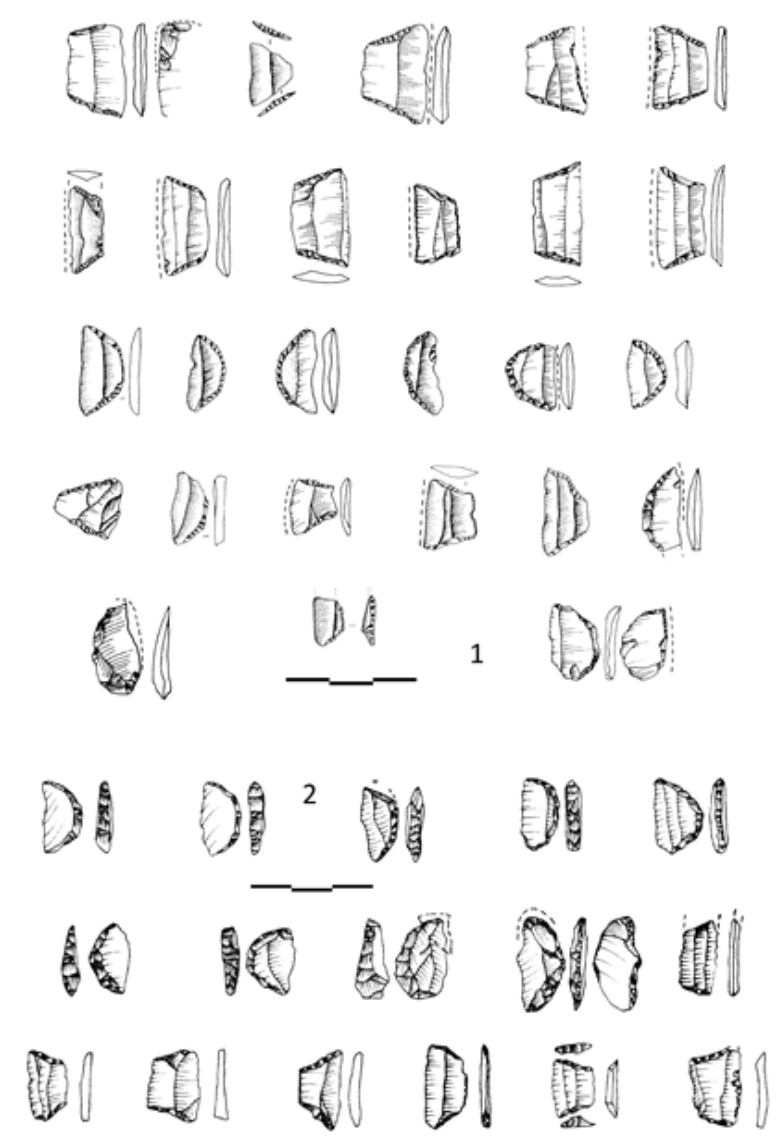

Fig. 10. Late Neolithic geometric microliths: 1 -from the site of Drama-Gerena (according to Lichardus et al. 2000, 4); 2 - from the site of Lyubimets (according to Анастасова 2012, 21, m.2) 
(C)2014

НЕОЛИТИЧЕСКИЕ КРЕМНЕВЫЕ АНСАМБЛИ БОЛГАРИИ: ОБЗОР ПРОБЛЕМЫ

М. Гюрова, кандидат наук, доцент

Институт археологии и музей НАН Болгарии, София (Болгария)

Аннотаџия: Статья содержит краткий обобщайщий обзор кремневых ансамблей неолитического периода в Болгарии (VI тыс. до н.э.). Прослеживается их эволюция, которая в зависимости от контекста имеет разные проявления и может быть названа по разному - инновация или трансформация. В течение неолита обнаружены некоторые существенные изменения, которые касаются всех аспектов кремневой индустрии: происхождения, добычи и использования кремневого сырья; технико-типологические параметры индустрии; функциональные характеристики отдельных категорий артефактов. Основное проявление этих изменений состоит в микролитизации индустрий. Эмпирическая база исследования состоит из колекций, происходящих с 18 неолитических поселений. Выявленны особенности эволюционного развития кремневых ансамблей из теллей и отмечены отличия по сравнению с коллекциями из кратковременных обьектов иного предназначения. На базе широкой основы представленного материала в статье в форме дискуссии сформулированы некоторые существенные вопросы относительно нашего знания и осмысления неолитического образа жизни.

Ключевые слова: неолит; кремневые ансамбли; характерные типы орудий; микролитизация; Балканский кремень.

УДК 902.2

ПАЛЕОЭКОЛОГИЧЕСКИЕ УСЛОВИЯ ОБИТАНИЯ ПЛЕМЕН ЭПОХИ НЕОЛИТА И (C)2014 ЭНЕОЛИТА В ПЕСКАХ ВОЛГО-УРАЛЬСКОГО МЕЖДУРЕЧЬЯ

И. В. Иванов, доктор географических наук

Институт физико-химических и биологических проблем почвоведения РАН, Пущино (Россия)

И.Б. Васильев, кандидат исторических наук, доцент кафедры отечественной истории и археологии Поволжская государственная сочиально-гуманитарная академия, Самара (Россия)

Аннотация: В статье представлена реконструкция палеоэкологических условий по древним почвам, отложениям, данным палинологии и палеозоологии. Природа развитого и позднего неолита соответствовала современной полупустыне, эпохи энеолита - более влажным сухим степям. Развитие ландшафтов и общества в Рын-песках на протяжении голоцена было прерывисто-дефляционным, неоднократно прерываясь периодами кризисов аридизации с активными эоловыми процессами.

Ключевые слова: неолит; энеолит; палеоэкология; палеопочвы; прерывисто-дефляционное развитие природы и общества.

Реконструкция палеоэкологических условий и влияния природных условий прошлых эпох на жизнь древних обществ - актуальные вопросы археологии и древней истории, палеогеографии и палеопочвоведения. Территория Рын-песков - удобный объект для таких реконструкций. Работа подготовлена И.В. Ивановым по материалам книги: И.В. Иванов, И.Б. Васильев «Человек, природа и почвы Рын-песков Волго-Уральского междуречья в голоцене» [1]. Археолог Игорь Борисович Васильев (1948-2004) является полноправным соавтором данной статьи, несмотря на то, что его сегодня нет с нами.

Общая характеристика территории. Рынпески расположены в низовьях рек Волги и Урала в Прикаспийской низменности. Большинство исследователей относят современные Рын-пески к ландшафтам полупустынной зоны с бурыми пустынно-степными почвами под лишайниково-злаково-полынной псаммофитной растительностью, некоторые - к ландшафтам пустынь. Исследовался модельный участок квадратной формы 100x100 км со стороной между селами Сеитовка - Тамбовка вдоль реки Ахтуба. Большая часть модельного участка расположена ныне в Астраханской области РФ, другая, меньшая - в Атыраусской области республики Казахстан.

Современный климат - сухой, континентальный с коротким весной и осенью (по 1,5-2 месяца) и длительным летом и зимой. Количество атмосферных осадков 120 150 мм, испаряемость около 1000 мм, средние температуры июля $+25^{\circ}$, января $-8^{\circ}$, года $+7^{\circ}$. Осадки часто имеют ливневой характер, снежный покров неустойчивый, в отдельные зимы образуются снежный наст, ледовая корка, приводящие к гибели животных (явление «джут»).

На протяжении голоцена за 11500 лет континентального развития в Рын-песках сменилось, чередуясь, 14 различных климатических эпох (по подзональной принадлежности) со следующей их суммарной длительно- стью в годах и увлажненностью: степные и сухостепные - 4,1 тыс. лет (4 эпохи), 36\% времени, осадков 400-500 и 200-400 мм/год: полупустынные - 3,5 тыс. лет (5 эпох), 30\% времени, осадков 150-200 мм/год; пустынные - 2,4 тыс. лет (4 эпохи), 21\% времени, 100-150 мм/год; перигляциальные - 1,5 тыс. лет (2 эпохи), 13\% времени

Рельеф Рын-песков - волнисто-равнинный, средняя высота над уровнем мирового океана $-10,-11$ м (современный уровень Каспийского моря - 26 м). Распространены протяженные понижения с солончаками; эоловые котловины различных размеров и глубин. В наиболее активных котловинах встречаются многочисленные грибовидные эоловые останцы - столбы, до 3 м высоты и 1 м ширины. Амплитуда колебаний мезорельефа в целом составляла преимущественно около 5 м (до 10 м). Пески богаты пресными грунтовыми водами, расположенными в понижениях на глубинах 2-3 м.

Мелкозернистые пески и супеси, слагающие поверхность, исходно имеют морское и аллювиальное происхождение, полевошпатово-кварцевый состав (полевых шпатов 8-23\%). Полимиктовость песков благоприятствует почвообразованию.

На большей части территории пески неоднократно перевеяны. В среднем в половине почвенных разрезов глубиной более 1,5 м (из двухсот разрезов) встречаются почвы, погребенные эоловыми песками. Большинство археологических памятников обнаружены благодаря дефляции, по этой же причине памятники имеют разную сохранность. Перевевание и переотложение песков происходило в аридные эпохи, почвообразование - в более влажные климатические эпохи. Из общего числа местонахождений с археологическим материалом (183) объекты с относительно сохранившимися культурными слоями и погребенными почвами составляют $11 \%$ от их числа. Относительно лучше сохранились культурные слои эпохи неолита ( $20 \%$ от местонахождений) и хуже 